\title{
Partial reinforcement with a small number of acquisition trials: Modified extinction procedures'
}

\author{
Garvin MeCain \\ ARLINGTON STATE COLLEGE
}

\begin{abstract}
Abstraet
One group of rats received six trials with $50 \%$ reinforcement, another received $100 \%$ reinforcement. Each group was given six extinction trials; each extinction trial was preceded by a reinforced trial which was given under new stimulus conditions. The $50 \%$ group ran slower than the $100 \%$ group in extinction and faster when the new stimulus was present.
\end{abstract}

\section{Problem}

Capaldi (Bloom \& Capaldi, 1961; Capaldi \& Stanley, 1963) has revised the aftereffects analysis of partial reinforcement. The partial reinforcement effect (PRE) is assumed to occur due to locomotor responses $\left(R_{10 c}\right)$ being followed by reinforcement while the stimulus aftereffects of nonreinforcement $\left(\mathrm{S}^{\mathrm{N}}\right)$ are present for partial reinforcement groups $\left(\mathrm{P}_{\mathrm{gps}}\right) . \mathrm{S}^{\mathrm{N}}$ are present in the stimulus compound during extinction and since $\mathrm{P}_{\mathrm{gps}}$ have been reinforced previously when these stimuli were present, they run more vigorously during extinction. Consistent reinforcement groups $\left(\mathrm{C}_{\mathrm{gps}}\right)$ have not experienced $\mathrm{S}^{\mathrm{N}}$ in conjunction with reinforcement and extinguish relatively rapidly.

From these assumptions it is reasonable to predict that blocking or confounding $S^{N}$ by the aftereffects of reinforcement $\left(\mathrm{S}^{\mathrm{R}}\right)$ during the extinction period would result in decreased resistance to extinction for $P_{g p s}$. This decreased resistance to extinction could result in a situation where there was no difference between $P$ and $\mathrm{C}_{\mathrm{gps}}$ in extinction. A decrease in resistance to extinction by a $\mathrm{P}_{\mathrm{gp}}$ which made that group less resistant than a $C_{g p}$ would be easier to interpret. The present study was run to test the effect of a procedure designed to interfere with the capacity of $S^{N}$ to evoke $R_{10 c}$ during extinction.

\section{Method}

The Ss were 90-day-old albino rats.

The straight alley was 24 in long, with a guillotine door 8 in from the end of the alley forming a start box. The timer was started by opening the start box door and was stopped by a photoelectric cell 1-1/2 in from the goal box. A guillotine door 7 in from the goal box prevented retracing. The alley and goal boxes were made of plywood, painted medium gray, with a plexiglass lid.

The goal boxes were L-shaped with a food cup in the $\mathrm{L}$ arranged so that it could not be seen until $\mathrm{S}$ entered the goal box. There were four goal boxes, two black and two white, arranged so that the interior of only one goal box was visible from the alley at any time.

Ss were placed on deprivation on Day 1 , and handled for $1 \mathrm{hr}$. daily on Days 2 through 6. Days 3 through 6 ,
Ss were fed wet mash during the handling period. Days 7 through 10, Ss explored the maze. Description of the typical exploration procedure may be found in McCain et al (1962). On Day. 11, Ss were divided into two groups on a random basis and fed for $20 \mathrm{~min}$., $24 \mathrm{hr}$. before they were to be run on Day 12.

$\mathrm{Ph}$ as e I. Ss in Group $\mathrm{C}(\mathrm{N}=19)$ received six reinforced trials $\left(R_{\text {trials }}\right)$. Group $P(N=20)$ received six trials with an NRNRNR reinforcement pattern. Each $S$ was run to either a black or white goal box, but not both. A dish of mash was available on $\mathrm{R}_{\text {trials }}$; the dish was empty on nonreinforced trials $\left(\mathrm{N}_{\text {trials }}\right)$. Usual balancing procedures were used.

$\mathrm{Ph}$ ase II. Phase I was followed immediately by a 12 trial period. Both groups received six extinction trials, each preceded by an $R_{\text {trial }}$ to the brightness not used in Phase I. For example, Ss run to black in Phase I were reinforced on runs to white on odd numbered trials of Phase II. Even numbered trials in Phase II were extinction trials to black. The purpose of $R_{\text {trials }}$ to the new brightness was to interfere with $S^{N}$ and produce $S^{R}$. Ss remained in the goal box $20 \mathrm{sec}$. on all trials with a 15 sec. intertrial interval. Ss failing to reach the goal box in $30 \mathrm{sec}$. in Phase I, or $45 \mathrm{sec}$. in Phase II, were guided to the goal box.

\section{Results}

Figure 1 shows the data from Phase II plotted in blocks of three trials. Data were transformed by taking a logarithm of $(\bar{X}$ sec. +1$)$ and analyzed using a trend analysis (Edwards, 1960). Group P ran significantly slower on extinction trials than Group $C(t(37)=2.15$; $\mathrm{p}<.05$ ) while running significantly faster than Group $\mathrm{C}$

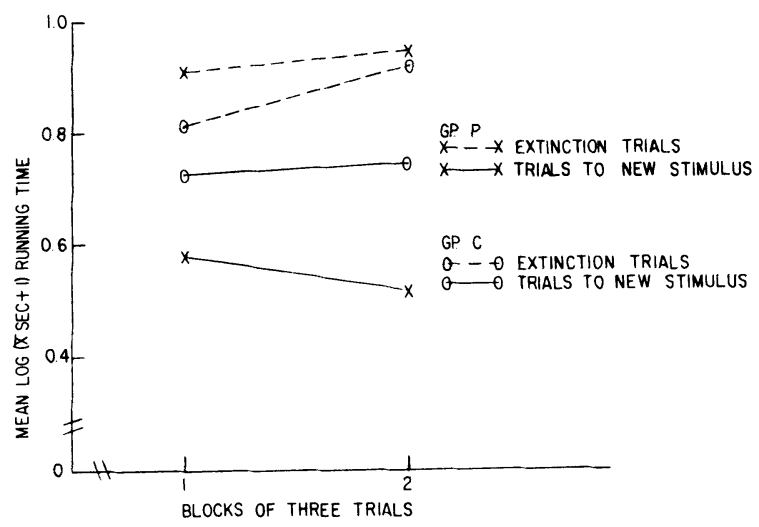

Fig. 1. Performance of the groups on extinction trials and trials to the new stimulus. 
on trials to the new brightness $(t(37)=6.00 ; p<.001)$.

$\mathrm{Ss}$ in the combined groups ran significantly faster on trials to the new stimulus in Phase II as compared to extinction trials $(\mathrm{F}(1 / 111)=9.50 ; \mathrm{p}<.005)$. This indicates Ss discriminated between the brightnesses.

\section{Discussion}

In the case of Group C, it was assumed that following each $R_{\text {trial }} S^{R}$ were present and were available as stimuli with which $R_{\text {loc }}$ could be associated on the succeeding $R_{\text {trial }}$ of Phase $I$. The situation was different for Group P. Each $\mathrm{N}_{\text {trial }}$ in Phase I produced $\mathrm{S}^{\mathrm{N}}$ and since each $\mathrm{N}_{\text {trial }}$ was followed by an $\mathrm{R}_{\text {trial }}, \mathrm{R}_{\text {loc }}$ was associated with $S^{N}$. Each $R_{\text {trial }}$ resulted in $S^{R}$ but an $\mathrm{N}_{\text {trial }}$ followed so that recurrence of $\mathrm{S}^{R}$ was less likely to evoke $\mathrm{R}_{\text {loc }}$.

In Phase II each extinction trial was preceded by an $R_{\text {trial }}$ to the new brightness. This affected the groups differently. Group C responded vigorously on extinction trials since $\mathrm{S}^{\mathrm{R}}$ was part of the stimulus compound and $R_{10 c}$ had been associated with $S^{R}$. Prior to Phase II, Group $P$ had not been reinforced when $S^{R}$ were present from the previous trial. On trials to the new stimulus both groups had $\mathrm{S}^{\mathrm{N}}$ present. Prior to Phase II, $\mathrm{S}^{\mathrm{N}}$ had not been accompanied by reinforcement for Group $\mathrm{C}$ but had been accompanied by reinforcement for Group
P. In summary, Group $\mathrm{P}$ was expected to run as slow or slower than Group $\mathrm{C}$ on extinction trials and as fast or faster than Group $C$ on trials to the new stimulus. The results agree with these predictions. Such results, taken together with the usually expected PRE in extinction, point to the difficulty of considering the PRE as a phenomenon. An analysis based on individual events leads to new predictions and emphasizes the need for analysis of each trial condition.

Finally, the PRE has been obtained when a small number of acquisition trials were used (McCain et al, 1962), so that the extinction results of the present study are not solely due to the number of acquisition trials used.

\section{References}

BLOOM, J. M., \& CAPALDI, E. J. The behavior of rats in relation to complex patterns of partial reinforcement. J. comp. physiol. Psychol., 1961, 54, 261-265.

CAPALDI, F. J., \& STANLFY, L. R. Temporal properties of reinforcement aftereffects. J. exp. Psychol., 1963, 65, 169-175.

EDWARDS, A. L. Experimental design in psychological research. (Rev. ed.) New York: Rinehart \& Co., 1960.

MCCAIN, G., LOVE, NANCEY, \& GRUER, W. Fxtinction as a function of a small number of partially reinforced trials. Psychol. Rep., $1962,11,451-454$.

Note

1. This study was supported by NIMH Grant MH-06981. Thanks are due to Donald Walker who ran the Ss. 